\title{
旅行業の発展によって景観地化する棚田
}

\section{Rice Terraces Becoming Landscape Areas by the Tourism Industry}

\author{
菊池真純* \\ Masumi Kikuchi* \\ *早稻田大学国際教養学部 \\ ${ }^{*}$ School of International Liberal Studies, Waseda University
}

\section{Iはじめに}

高齢化と後継者不足を主な原因として，山閒地・中山 間地農村の著しい衰退が進み，その対策案が議論されて 久しい。日本の中山間地の棚田保全に関して, 中島峰広は, 「棚田の基盤は拡大せず，収益性の低さや高齢化の進行な どにより，棚田の耕作放棄が一段と顕著になった。」い と述べている。また本論調查地のある中国農村においても 同様に，2000 年には，中国の高齢者人口の $65.82 \%$ 䓃農村 に居住し，農村の高龄化は都市部よりも梁刻である。 のように，今日，多くの地域で，高龄化や若者の農村・ 農業離れによる農村地域の衰退が深刻化しており，解決 策を模索することは困難を極めている。

そこで，本稿では，中国南部の山間地で棚田耕作を主 として農村経営を行っている平安村を事例として取り上 げる。この村でも，時代の変化によって，後継者不足や 旅行業による過度の開発といった諸問題が発生した。し かし，村では現在，住民の努力と政府の厳しい規制管理 のもとに，棚田景観を管理・維持している。この村の特 徵的な現象として，今日，村内の農業の担い手が減少す る一方で，旅行業の発展によって経済的に豊かになった この村へ，周辺の貧困農村から棚田耕作に出稼ぎに来る 人々が存在し始めていることが举げられる。今日この 村では，新たな農業の担い手を確保することによって， 棚田景観を核とした農村経営の継続と発展の形態を確立 しつつある。

本稿では, 棚田耕作の目的が, 食糧生産を主目的とし たものから，景観形成のためへと移行してきている調查 地の農業形態とそれを支える構造に関して，新たな担い 手の参入状況を中心に考察する。そこから，時代の変化 に応じながら，新たな担い手を確保し，資源と化した棚 田景観を維持することによって，山間地農村の維持・発 展を可能なものにしていこうとしている地域の一例を示 したい。

\section{II 調查方法}

現地調查結果は, 2010 年 3 月, 2012 年 2 月と 6 月に, 村民委員会と村民へ行ったインタビューによるものであ る。村民委員会は，村長にあたる村主任と書記（共産党の 役職で，各地域、学校や組織のなかで風紀委員のような 役割で存在している)に対して，村の統計資料や近年の変 化に関してインフォーマル・インタビューを行った。村 民に対する意識調査は，現在，平安村において村民のな かで差異を作り出しているのは，旅行業開始後の各家庭 の収入の差異であることが村幹部のインタビューから明 らかになった。さらに，中国農村では，個々人による行 動単位ではなく，家族単位が生活や意思決定の基準とな っていることから，年齢別や学歴別，性別による回答者 の選出基準ではなく，村での経済水準を基準として，最 高収入，高収入，中収入，低収入，最低収入という50 の村民のグループからそれぞれ 4 家庭を選出し、2010 年 3 月に, 合計 20 の家庭にインタビェーを行った。家 族の代表者として主に世帯主(家長) 1 名を回答者として インタビューを実施した。

\section{III 山間地の農村経営が直面する諸課題}

上述したように，近年多くの地域で若者の農業・農村 離れと高齢化による地域の衰退といった共通課題が存在 する。都市戸籍の農村戸籍という二元戸籍制度を有する 中国社会において，農業は貧しく，農村は発展が革れ， 農民は身分が低い，といった三農問題が，農業大国中国 において深刻である。さらに,こうした貧困から拢け出 すために，多くの農民が都市に出稼ぎに出ており，社会 保障等を持てない劣悪な条件のなかで，都市で出稼ぎを し，これが大きな社会問題となっており，こうした状況 も農村の衰退に大きく影響している。洋11 
他方では，急速な経済発展に伴い，都市の富裕層の多 くが週末や連休に農村へ出かけ，ルーラルツーリズムを 楽しむという新たな流行が中国においても始まっている。 3ここでの一般的な問題は，極度な開発や商業化による 農村社会の物質的，精神的な破壊である。その代表的な 失敗例として，1997 年に，世界遺産に登録された雲南省 の麗江がしばしば取り上げられるが，中国農村での旅行 業の進入のあり方は，商業優先による自然環境，民族文 化，地域コミュニティの破壊を招いている例が少なくな い。泳2こうした状況のなか，本稿では，地域独自の農 村景観を最大の資源として，地域の発展を目指す村を取 り上げ，その発展形態を考察する。

\section{IV 平安村の事例}

\section{1 平安村の概要}

平安村は, 中国南部の広西壮族自治区龍勝県和平郷の 東北部に位置し，村のなかには、平安一，平安二，平安 三，平安四，平安五，平安八，三龍，福禄という８つの 集落が存在する。村全体では 180 戸 797 人が生活を営ん でおり，その $98 \%$ 以上が壮族で，姓は廖である。村全体 の耕作地面積は 901 畧注3であり，そのうちで水田は 600 畧である。

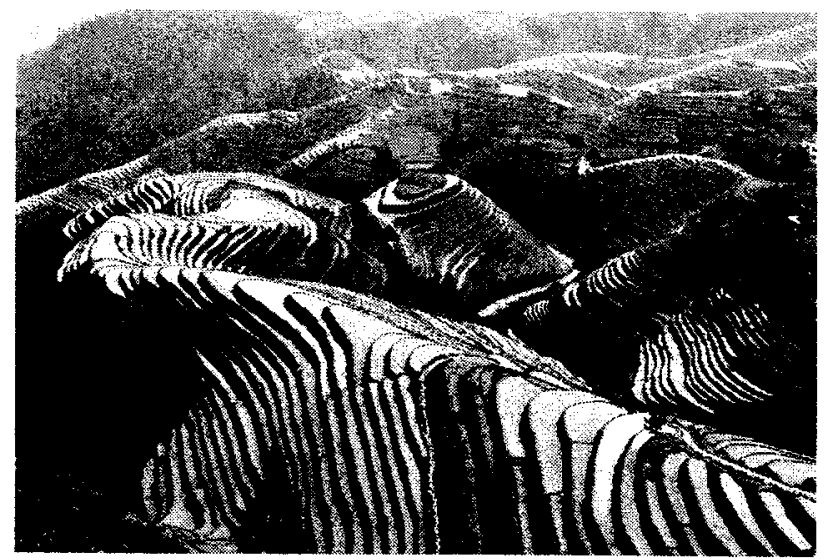

図 1 平安村の棚田

Fig.1 The trend of The Rice Terraces in Pingan Village.

注：1）筆者撮影 (2012 年 6 月)。

彼らの祖先は，山東省を起源とするが，宋の時代に慶 遠府南丹州(現在の広西南丹)に移り，その後, 元の時代 から同地域の山で生活をはじめたとされている。これら 移民の経緯には，戦乱や民族差別による弾圧から逃れて きたことが背景に存在する。1994 年に, 桂林のカメラマ ン李亜石がこの村の棚田景観を世間に紹介したことをき っかけに，棚田景観が大きく評価され、村を訪れる旅行
者が現れ始めた。1996年から，外部者が村に入る際に村 民独自で中国人 1 人 3 元，外国人 1 人 5 元でチケットを 売り，管理を始めたのが平安村での旅行業の最もはじめ の段階といえる。地理的にも辺鄙な山地に位置するため， それ以前の平安村は，外部との交流は少なく，閉ざされ た環境のなかで，ほぼ完全に近い自給自足の生活を 600 年以上行ってきた地域であった。

\section{2 旅行業の発展}

1999 年から，旅行会社が公式に旅行者に対する入場チ ケットの管理をはじめ，そのチケット収益の一部を平安 村に分配しはじめた。旅行会社が村民に対して分配する 際，当初はこれを「進寨費(入村費の意味)」と呼んでい たが,棚田保全のために使用するという名目のもと後に，

「梯田維護費 (棚田維持費の意味)」という名称に変わっ た。現在，このチケットは，旅行者 1 人につき 50 元とな つている。旅行会社から村民に分配されるチケット収益 の一部は，平安村村民の旅行業収入のなかのごく一部分 であり，その他に，大部分の家庭が民宿や飲食店を開い て収入を得ている。

表 1 は，旅行会社が管理する村への入場チケットによ る収入を一定の比率で平安村に分配しはじめた 1999 年 から 2007 年までの龍脊棚田風景区の入場チケット収入 と平安村の全体所得を示したものである。これは，旅行 会社が管理するチケット收益全体の額であり，ここから $7 \%$ が村に支払われ，さらに村内の各戸に分配されている。

表 1 平安村における龍脊景区入場チケット収入と 平安村所得の変化

Table 1 The outline of The Ticket Ernings and The Total Income of Pingan Village

\begin{tabular}{|c|c|c|}
\hline 年 & チケット収入(万 RMB) & 平安村所得(万 RMB) \\
\hline 1999 & 23.41 & 2 \\
\hline 2000 & 37.93 & 2.5 \\
\hline 2001 & 62.6 & 3 \\
\hline 2002 & 209 & 15 \\
\hline 2003 & 263 & 15 \\
\hline 2004 & 539.22 & 35 \\
\hline 2005 & 756 & 35 \\
\hline 2006 & 958 & 35 \\
\hline 2007 & 1276 & 73 \\
\hline
\end{tabular}

注：1）平安村村民委員会提供資料。

2003 年に国道 321 が龍勝から桂林まで完全開通し，こ の閒の移動時間はわずか 1 時間半となった。表 1 をみて 
もわかるようにこの開通を前に，すでに 2002 年以降， 大型バスを利用した団体旅行のコースに組み込まれはじ めたため，大幅な収入の増加が見られる。したがって入 場チケットは, 2001 年の 62.6 万元が 2002 年には約 3.3 倍の 209 万元一増加し, 平安村の所得は, 2001 年 3 万元 から翌年 2002 年には 5 倍の 15 万元と大幅に増加してい る。その後も，年々大幅な伸びがあることが確認できる。 2009 年から, 平安村の入り口に「平安村概要」と書か れた看板が設置されはじめた。そこには，村に関する簡 単な紹介と共に、「平安村はすでに旅行業を主要産業とし， 農業はそれを補う産業となっている」という一文が明記 されている(図 1，6〜7行目：「目前，村内已形成以旅游 業為主、農業為輔的産業格局。」)。

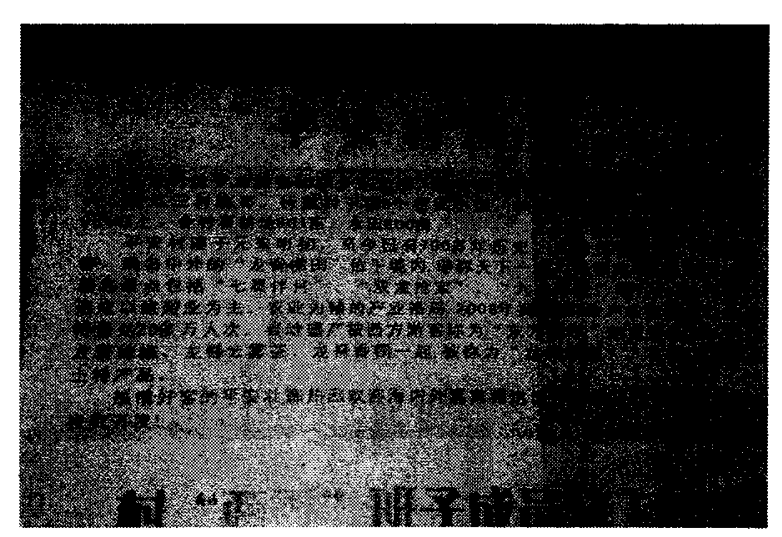

図 2 平安村入りロにある村を紹介する看板

Fig. 2 The trend of The Introduce of Pingan Village

注：2）筆者撮影 (2010年 3 月)。

\section{3 政府の規制による棚田の整備}

旅行業がはじまってから 2005 年までの間, 政府とい くつかの旅行会社の協同によって, 旅行者への入場チケ ットや村内の歩行道の整備, 村民への棚田耕作継続の指 導や建築規制の指遒といった管理が行われてきた。その 後, 2005 年以降は, 現在の桂林市温泉旅行有限責任公司 という旅行会社が村の旅行業全体を管理している。この 旅行会社も政府との協同が強く，多くの村民は，「旅行会 社=政府」という認識をしている。

入場チケット管理の以外に，平安村の棚田保全に対す る政府の制度規制による介入は，様々な形式で行われて いる。龍勝県政府旅游局は, 1999 年から, 村内の小道の 整備, 展望ポイントの設置, 村民に対する棚田景観保全 の呼びかけ，対外への村の宣伝活動を行い始めた。その 後, 2005 年から龍勝県政府が平安村に「県級景区管理室」 を設置し，現在に至る。この主な任務は，棚田景観を保 全するために，家屋建築の場所を規制するものである。

これまでは棚田周辺に関する規制が中心であったが，
2008 年からはさらに具体的に棚田耕作に関する内容人 の規制が，龍勝県農業局の管轄のもと行われるようにな った。具体的には, 晆の草刚, 耕作放棄地の消滅, 農閑 期にも水を張り保水田を形成して景観を保つこと，春に は棚田に菜の花を植えて景観を保つことなどが举げられ， それに対する技術指導や補助金の導入が行われている。 また，高龄者のみの家庭をはじめとして，その家庭で自家 の田の耕作が困難な場合は, 他者に委託することを義務 づけられている。

また最も新しい規制は，2月末から $3 ４$ 月にかけて棚 田に植えられている菜の花プロジェクトである。旅行会 社が主導となり，1畧あたり 100 元分の菜の花の種や肥 料にかかる費用を旅行会社が農家に対して負担し，その 後さらに，1畧あたり 100 元の補助金を農家に支払って いる。この後者の 100 元に関しては,検査基準は峳しいも のではないものの, 開花後の検査を経て, 合格した農家 に支払われている。この菜の花の栽培は農業本来の目的 ではなく，農閑期である初春の棚田景観に彩りを添える， 完全に旅行業のための意図的な景観形成となっている。

平安村では旅行会社と政府の風景区維持・管理に対す る介入が大きく，厳しい管理指導を受けていることによ って，1年を通して風景区の行き届いた棚田管理を実現 させている。政府と旅行会社が旅行業によって利益を上 げようと考えるうえで，2 号風景点と呼ばれる七星伴月 風景点は, 平安村の顔となっている。観光バスでこの地 域に訪れ，ここで宿泊をしない団体旅行の一行は，一般 的に時間の制限により, 平安村の 2 号風景点のみを参観 する場合が多い。したがって，政府と旅行会社は，2号 風景点の棚田整備に対して，他の地域よりもさらに集中 的に管理指導や菜の花栽培の際の補助金の投入に力を入 れている。

こうした状況によって，自分たちの村では現在，旅行 業のために棚田耕作を行っているのであり，棚田耕作は 補助金や給料を受け取って行うという考えが住民たちに 根付きはじめ，村では農業が主体ではなく，旅行業が主 体となっている，という認識をさらに強めている。旅行 業が始まり，政府の管理が厳しくなったことによって， それ以前よりも棚田景観が美しくなったと述べる村民が 多くみられた。

\section{4 村内の担い手不足}

旅行業が地域に進出し，村に農業と旅行業の兼業化が 生まれた。その結果，まず，(1)地域内住民の階層分化が 発生した。(1)複数の旅館を経営する者，(2)一軒の旅館を 経営する者，(3)飲食店を経営する者，(4)工芸品店を経営 寸る者，(5)路上で工芸品を売る者，(6)旅行者に地域内を 
案内する者，(7)旅行業にはほぼ関与しない者，というよ らに地域住民の旅行業への様々な参入形態があり，それ によって仕事と生活の形態が人によって異なり，経済収 入も異なる。この点が，地域で皆が自給自足をしていた 十数年前までの生活とは変化した最も大きな点である。 次に，(2)家族内での役割分担の明確化が挙げられる。調 査のなかでは，1 つの家庭のなかで，若者である息子夫 婦は農業には携わらずに村内で旅行業に携わる，或いは 出稼ぎに出て村を離れ，高齢者の父と母が村で農業に携 わるといった形態が一般的になっている。これも兼業化 による家庭内での差別化である。こうした若者の農業離 れと農業従事者の高龄化は, 他の山間地農村同様に, 平 安村においてもみられる現象である。

棚田耕作を行う目的を農業と旅行業の関係のなか力ら 村民に意識調査した結果，以下の回答が得られた。

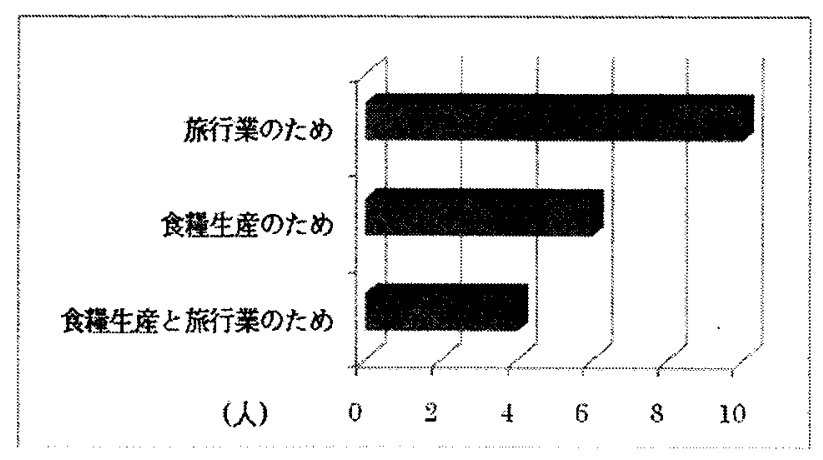

図 3 棚田耕作を行う現在の目的(複数回答)

Fig. 3 The trend of The Purpose of Farming Rice Terraces

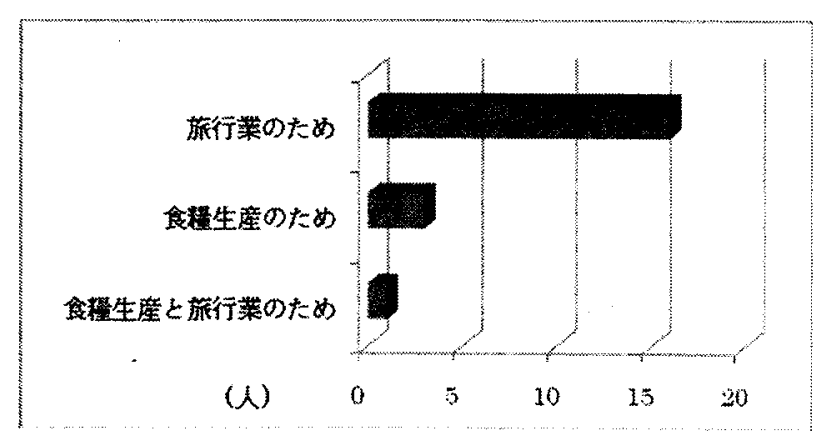

図 4 将来的な棚田耕作の動機 (褚数回答)

Fig. 4 The trend of The motive of Farming Rice Terraces in the Future

図 3 の現在の棚田耕作を行う目的におかいて, 半数が「旅 行業のため」と回答をし, 6 名が「食糧生産のため」，4 名が「旅行業と食糧生産のため」と回答をした。図 4 の 将来の棚田耕作の動機としては，さらに多くの過半数を 超える 16 名が「旅行業のため」と回答をしている。

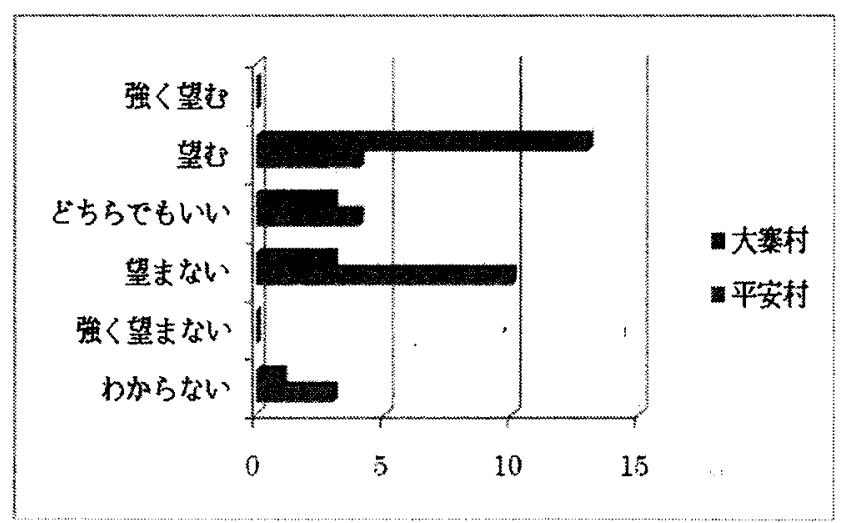

図 5 子女に対する村内定住への意向

Fig.5 The trend of The Hope to Posterity Settle Down in The Village.

また将来，自分の子供たちに村に残って生活をしてほ しいと望むか否かに関する質問には，図５で示したよう に，同じく大規模な棚田を有する近隣の大寨村村民の大 部分が望むと回答しているのに対して，旅行業の発展し ている平安村では，望まないという回答が最も多いこと がわかった。

この理由として，旅行業の発展による経済的余裕や道 路等インフラの整備によって，村民の教育水準も大きく 向上したことが背景に挙げられる。近年, 全ての子供が 小中学校の義務教育を終え, 高校への進学者も毎年約 60 〜 70\%となっており，さらに近年では，毎年 $2 \sim 3$ 人の大 学進学者を出している。村では高等教育の支援として、 村からの大学進学者に対して, 入学時に 2000 元の奨学金 を支給している。村の書記の子息もインタビュー時に， 広西の政令指定都市である南寧市の大学の学生であった。 廖書記も，自身の子供が将来平安村に戻って生活するこ とには強い反対の意向を示しており，平安においては， 多くの家庭の父母が同柡の意見を持っている。この最大 の理由として，農村での苦労を自分の子供にはさせたく ないという考えがあり，可能であれば自分の子供には都 市での発展・飛躍を望むという考えがあることがわかっ た。

\section{5 平安村に出稼ぎに来る人々}

棚田があることで旅行業が発展しはじめ，今日の平安 村が存在する。つまり，棚田がなければ，旅行業が成り 立たないといえる。しかし，今日，若者の農業離れによ って，村内における農業の担い手が不足し，それは今後 さらに顕著なものとなることが予想されている。こうし たなか，一方で，今日，村における新たな農業の担い手 として，周辺の極貧農村から平安村に棚田耕作に来る出 稼ぎの人々が存在し始めている。 
現在，平安村において，景観地とされている地帯は 100\%耕作を行っており，耕作放裹地は存在しないが，旅 行客が訪れることはほぼない村の奥には耕作放棄地も存 在する。こうした村内の全ての棚田を包括してみると， 現在，平安村での耕作放棄地は，全体のなかで約 $18 \%$ 存 在し，残りの $82 \%$ を耕作している状況である。

中国において，土地は，個人のものではなく，国家あ るいは集団に属するもので，個々人は単にその使用権を 有する。平安村でも，村から各戸に耕作地が分配されて おり，村内の棚田や家屋等の土地は全て村民に使用権が ある。現在も耕作を行っている棚田の耕作者の内訳をみ ると，自分たちの家庭に分配されている棚田を自家で耕 作している村民の割合は約 65\%であり, 自家で耕作を行 わず，村内の別の家庭に耕作を委託している割合は約 $30 \%$ 存在する。さらに，自家で耕作を行わず，また村内 の他の家庭に委託をせず，周辺農村から平安村に出稼ぎ に来ている農民に委託している割合は約 $5 \%$ となってい る。そこでの具体的な棚田耕作の委託条件は, 一般的に, 他の村民に耕作を委託する場合には，自家の棚田周辺の 村民に委託をし，そこで収穫した米は，全て委託された側 のものとなる。

村外部の周辺地域から出稼ぎに来る農民に対しては， 委託する側が,出稼ぎの人々に対して食事と宿泊場所を 提供し,住み込みによって棚田耕作を委託する。さらに 1 日 25 元の賃金を支払うのが一般的であり,村では，この 食事代と宿泊場所の他に，賃金 100 元を支払うのが一般 的である。これは，先に示した平安村の所得平均から考 えても非常に高い金額であり，現在，出稼ぎの人々を雇う ことができているのは，外部から投資を受けて旅館を開 いている村内でも最富裕層にあたる家庭である。

現時点において，棚田耕作に村に出稼ぎに来る周辺農 村の農民の割合は, 約 5\%程度である。しかし, 旅行業 の村への進出や若者の出稼ぎによって, 村内で他の家庭 に棚田耕作を委託する人々が, 現在すでに約 $30 \%$ 存在す ることから, 今後も村内外への委託が進んでいくことが 予想されている。さらに, 村民委員会では, 将来, 村内 で棚田耕作を行う人なが存在しなくなることを予想し， 政府が周辺農村地域から農民を集め，政府の雇用のもと に, 平安村の棚田耕作が行われていく可能性を示唆して いる。

\section{$\mathrm{V}$ 景観地化する平安村の棚田への評価}

\section{1 肯定的に評価できる点}

平安村では外部の変化に伴い, 地域内部の変化が生ま れているなかで，制度による規制を通して，農村景観の
動態的保全を行っている。平安村では, 外部要因の影響 を大きく受けたことによって，地域内の人々の価值観の 変化, また資源管理をはじめとする地域内での規則・規 範の変化が生じ, 地域の人々の生活を変化させた。それ に伴い, 地域生活の総体的表現である農村景観にも変化 が生まれることとなる。しかしこうした一連の変化の なかでも，旅行業の重要な資源である農村景観を保全し ていくために，政府・旅行会社が設けた制度によって， 景観管理が実現されている。先に示した地域住民の回答 にもみられたように，旅行業開始以前よりも現在の棚田 は整備され，農村景観は美しくなってきているという理 由は，この制度での規制による成果だと考えられる。換 言すれば，時代の変化と共に人々の生業が変化したこと によって, 本来, 崩壊・消滅するはずの地域の伝統的農 村景観を強制的に整備・維持している状況である。これ に関して, 現在, 平安村の農村景観は、制度によって保 全·維持され, 景観地化する傾向が強まってきているが， これも時代の変化のなかでの 1 つの動態的保全の形とい うことができる。

これまで述べてきたように，平安村は，外部からの旅 行者の需要に敏感に反応して，すでに市場経済に対応し た旅行業を確立している。したがって, インフラ, 商業 施設，景観が整備されており，大量の短時間滞在旅行者 を受け入れているため，村の住民の平均収入も周辺地域 から抜きん出て多い状況である。これは，貧困地域とさ れてきた中山間地域農村の発展という枠組みのなかで, 1 つの成功として評価をすることができる。

\section{2 新たな課題}

今日，平安村において棚田の役割に変化はあるが，棚 田を地域最大の資源として，今後も発展を目指していく 村内で, 外部から出稼ぎに来る人々をどう捉え，また本 来, 平安村の壮族文化の一つである棚田耕作を出稼ぎの 人々が行う場合，その文化的意義はどう変化するのかと いう課題が挙げられる。

出稼ぎに来る周辺地域の人々もまた類似の地域環境の なかで農業を営む農民であることから，将来，仮に大部 分の棚田を彼らが耕作する状況になったとしても，棚田 は整備・管理されていくと考えられる。しかし，農村固 観を形成する要素は，単に農業技術のみにとどまるもの ではなく，そこで暮らす人々の民族や宗教といった文化 的要素をも包括しているものである。今後，平安村村民 が棚田耕作には関わらないようになれば，それは，壮族 が 600 年以上この地で棚田を中心とした生活のなかで築 き上げてきた文化は失われることを意味すると考えられ る。この文化の変容は, 社会の変化と旅行業が生み出し 
た $1 つ の$ 弊害であるといえるが，しかし，伝統文化や生 態環境を守るために，地域の人々の生活を限定的なもの として犠性にするのであれば，その発展形態は持続可能 なものとはいえない。新たな農村運営形態が展開され始 めている現在，出稼ぎに来る人々も，村の共同体の構成 員に変わりはない。

平安村は，外部との交流のない自給自足による地域内 での自己完結型の生活から，外部社会との交流・連携・ 補完による関係性のある生活へと変化を遂げてきた。そ れに伴って，地域に関わるアクターが地域住民の枠を超 えた多様化と広範囲化が進むなかで, 共同体の構成員は， こうした外部のアクターを含んだ多様化・広範囲化した 共同体のあり方を認めて発展を目指す必要がある。村民 が村の将来の方向性を決定し，地域の主体アクターであ ることは重要であるが，すでに現在、政府・旅行会社・ 出稼ぎ農民・旅行者といった多様なアクターが，様々な 方法を通して地域の農村景観の維持と活用に貢献してい る。地域の農村景観が資源として存在するためにはこ うした外部社会の多様なアクターの協力・支援を得て協 働していくことが必要不可欠である。

\section{VIおわりに}

今日，一部の地域に敌ける農業の目的は，従来からの 食糧生産を目的とする以外に，環境保全・景観保全のた めの目的に移行している地域が存在している。例えば, 本稿調查地の平安村と揚子江周辺の平野地農村を従来の 農業の基準によって比較した場合，その収穫量・品質・ 農作業の効率の全てにおいて，平安村が大きく劣ること は容易に結論づけられる。しかし，従来の農業の目的以 外に，第 2 の目的が市場経済と社会のなかで確立しはじ めたことによって，豊かな森林資源のなか少数民族が生 活を営む棚田景観を有する村の特徵を活かすことが可能 となった。ただし，景観保全のための農業は，農業のみ
ではなく，農業と平行して旅行業の発展が必要亡なる。 新たな農業の目的と形態は，これまで農産物の生産量が 低く，貧困地域とされてきた農村における活路を生み出 しているという点からも肯定的に捉えることができる。 多面的な機能を持つ農業という産業は，必ずしも食糧生 産のために行われるべきと限定されるものではなく，食 糧生産以外にも多様な目的・形態名存在して良いと考え られる。またそこに携わるアクターも，時代の変化と伴 に多様性を認めていく必要があると考えられる。

\section{注}

注 1) 統計によると，2009 年 11 月には，中国全土で, 1 億 5200 万人の農民が都市に出て,出稼ぎをしてい る。陳鍚文 (2010)：当前農業和農村経済形勢於 “三 農”面臨的挑戦：中国農村経済，中央農村工作， 第 1 期，北京， p. 5 .

注 2 ）麗江に関して、李公明は、「政府と業者、それに御 用達学者が加わって利益を追い求め、少数民族本 来の暮らしという視点を欠いた観光振興は問題 だ」と指摘している。世界遺産登録後から現在ま で、地域住民であった納西族の半数以上が、地域 の商業化を嫌い、移住を選択している。読売新聞、 2010 年 1 月 30 日。

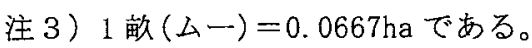

\section{引用文献}

1) 中島峰広 (1999): 日本の棚田一保全への取り組み. 古今書院，東京，p. 17.

2) 邵興華 (2007)：農村人口老齢化若干問題研究：中共 烏魯木斉市委党校学報。第 1 期，鳥魯木齐，p. 23 .

3) 何麗芳 (2006) : 鄉村旅游於伝統文化. 地震出版社, 北 京, pp. 169-171.

4) 李富強 (2009)：現代背景下的郷土重構：龍背平安寨 経済与社会変遷研究, 科学出版社, 北京, p. 56

Summary: Most of mountainous regions in Asian countries have seen penury and aging. It is serious problem in long time. As an example I would like to point out Ping-an village, Guangxi, China. They have been self-sufficient through the cultivation of rice terrace. Nowadays when the development of existing resources in less-favored rural areas is aimed, the rural landscape until now never considered as resource, may turn out to be the most valuable one. At the same time, the rice terraces becoming landscape areas by tourism industry in Ping-an village. Thus the observation of the process of change of the rural landscape into resource becomes possible.

キーワード (Keywords）: 中国農村（Countryside in China），棚田（Rice terrace），景観地（Landscape Areas），ルーラルツ 一リズム (Rural Tourism) 